Chirurgia (2018) 113: 385-390

No. 3, May - June

Copyright $\odot$ Celsius

http://dx.doi.org/10.21614/chirurgia.113.3.385

\title{
Severe Acute Pancreatitis - Determinant Factors and Current Therapeutic Conduct
}

\author{
Silviu Constantinoiu', Daniel Cochior ${ }^{2}$ \\ ${ }^{1}$ General and Esophageal Surgery Clinic, Center of Excellence in Esophageal Surgery, "St. Mary" Clinical Hospital, \\ "Carol Davila" University of Medicine and Pharmacy, Bucharest, Romania \\ ${ }^{2}$ Clinic of General Surgery, Monza Hospital, Titu Maiorescu University, Bucharest, Romania
}

Corresponding author: Professor of General Surgery Dean of Faculty of Medicine Titu Maiorescu University Clinic of General Surgery Monza Hospital, Bucharest E-mail: cochiordanie|@gmail.com

\section{Rezumat \\ Pancreatita acută severă - factori determinanți și atitudine terapeutică actuală}

Aşa cum a fost considerată de Dieulafoy şi cum a rămas, pe drept cuvânt „marea drama abdominală”, pancreatita acută a constituit întotdeauna, rămânând ca atare şi în prezent, o adevărată provocare diagnostică şi terapeutică din cauza variabilității sale etiologice, clinice şi biologice, caracterului imprevizibil al evoluției şi dificultăților de stabilire a tratamentului adecvat fiecărui pacient. In acest context s-au confruntat de-a lungul timpului concepții diferite, uneori diametral opuse, cu privire la interpretarea cazurilor şi la algoritmul terapeutic adoptat, dovadă stând numărul foarte mare de lucrări consacrate acestui subiect. Ințtelegerea mai aprofundată a fiziopatologiei pancreatitei acute odată cu creşterea interesului în clasificarea severitătii pe baza factorilor determinanți (locali şi generali) reprezintă factori decisivi în preconizarea severității şi adoptarea strategiei terapeutice moderne a acestei maladii complexe şi heterogene.

Cuvinte cheie: pancreatita acută severă, factori determinanți, disfuncție multiplă de organe (MODS), necroză închistată (WON walled of necrosis), necrozectomie, tehnici chirurgicale hibride

\section{Abstract}

Considered by Dieulafoy as the "great abdominal drama", acute pancreatitis has always been, and still remains, a real diagnostic 
and therapeutic challenge because of its etiological, clinical and biological variability, the unpredictable evolution and the difficulty of establishing appropriate treatment for each patient. In this context, various, sometimes diametrically opposed, conceptions about the interpretation of the cases and the adopted therapeutic algorithm have been encountered over time, as evidenced by the great number of papers dedicated to this subject. A more thorough understanding of acute pancreatitis pathophysiology, with increasing interest in severity classification based on determinant factors (local and general) are decisive factors in predicting severity and adopting the modern therapeutic strategy of this complex and heterogeneous disease.

Key words: severe acute pancreatitis, determinant factors, multiple organ dysfunction (MODS), walled of necrosis (WON), necrosectomy, hybrid surgical techniques

\section{Introduction}

Acute pancreatitis is an inflammatory disease of the pancreatic gland that can evolve to SIRS and sepsis, thus becoming a systemic disease. In adults, the most common causes are gallstones and alcohol consumption. Clinically, the onset of acute pancreatitis is fully alert to the severity of local and systemic signs. The rapid evolution of pathological sequences does not allow hesitations, and especially mistakes in the adopted therapeutic attitude.

The clinical spectrum of acute pancreatitis can range from moderate forms, with inflammatory syndrome only of the pancreas, to moderate-to-severe forms with SIRS (systemic inflammatory response syndrome) and transient multiple organ disfuntion syndrome (MODS) with or without local complications and which can be fully recovered under treatment, to severe forms with pancreatic and/or peripancreatic necrosis and persistent organ dysfunctions, forms characterized by high mortality $(1,2,3)$.

The revised classification (Bologna) identifies two evolutionary phases of acute pancreatitis corresponding to two peaks of mortality $(4,5)$ : the early phase (the first 7-14 days with systemic inflammatory response syndrome (SIRS) and early MODS / MSOF) and the late phase (2-6 weeks of evolution, with anti-inflammatory compensatory syndrome (CARS), intestinal bacterial translocation, infected pancreatic and peripancreatic collections, tardive MODS / MSOF).
These two phases are distinct from the pathophysiological point of view. The first phase is characterized by the presence or absence of organ dysfunction (systemic determinants) and very little local peripancreatic changes (local determinants). Therefore, we can say that it is characterized by "functional" or "clinical" aspects that lead to conservative therapeutic behavior (4). Unlike the first, the second phase is characterized by the symptomatology determined mainly by the evolution of local complications at the pancreatic / peripancreatic level, which can also manifest itself systemically through bacteremia and sepsis. Thus, in the tardive phase, the "morphological" criteria lead to specific therapeutic sanctions and which do not overlap with the criteria in the early phase (5).

The hierarchy of the severity of acute pancreatitis remains the key element in addressing this pathology (6).

The dynamic nature of the disease has a direct impact on the severity of the disease during the course of evolution. Mortality and morbidity are important for severity (risk groups): patients with increased morbidity and mortality (severe form), patients with high morbidity and low mortality (moderate-tosevere), and low morbidity patients without mortality (moderate form) $(7,8)$.

\section{Material and Method}

The prospective study (2000-2017) was based 
Table 1. Patient characteristics based on the moment of surgery

\begin{tabular}{|c|c|c|c|}
\hline \multirow{2}{*}{$\begin{array}{l}\text { Characteristics } \\
\text { ( } n=157 \text { cases operated) }\end{array}$} & \multicolumn{2}{|c|}{ Moment of surgery } & \multirow[t]{2}{*}{$P$ value } \\
\hline & $\begin{array}{c}\text { Day } 7-28 \\
(n=87)\end{array}$ & $\begin{array}{l}\text { More than } 28 \text { days } \\
\qquad(n=70)\end{array}$ & \\
\hline 1 preoperative organ dysfunction (56\%) & 52 & 36 & 0.2 \\
\hline$>2$ preoperative organ dysfunctions $(36,3 \%)$ & 28 & 29 & 0.4 \\
\hline Period of hospitalization ICU (average) & 27 & 37 & 0.25 \\
\hline Antibiotic therapy $>30$ days $(20,3 \%)$ & 11 & 21 & 0.04 \\
\hline Average usage time of antibiotic therapy (days) & 17 & 23 & $<0.001$ \\
\hline Average number of antibiotics used & 2 & 2 & 0.3 \\
\hline Candida infection $(\mathrm{n}=14 ; 8,9 \%)$ & 5 & 9 & 0.5 \\
\hline Multi-resistant germ infection $(n=22 ; 14 \%)$ & 8 & 14 & 0.28 \\
\hline
\end{tabular}

on a hierarchy of severity and therapeutic management protocol that we have improved over time according to the results and literature data. The results obtained have also been analyzed in terms of consistency with the recommendations of the Bologna Consensus Conference (1). Of the 297 cases of severe acute pancreatitis hospitalized in two surgical clinics, 157 (61\%) had surgical indication (Table 1).

In 104 cases, we have performed laparostomy of the lesser sac. We have analyzed he severity hierarchy, the principles of conservative therapy, the indication of surgical treatment, the timing of surgery, the status of the patients at the time of surgery (organ dysfunction / insufficiency, local complications, comorbidities), comparisons with literature data. The recorded data was statistically processed using the SPSS (Statistical Package for Social Sciences) version 17 for Windows.

\section{Results}

All patients with severe form were intensively treated in ICU. Treatment in ICU makes it possible to reduce mortality in the first 2 weeks of evolution of the severe form, which determines the possibility of abstaining from surgery performed in this interval. These delayed, elective surgeries provide the necessary time for the immune system to "encapsulate" the necrotic tissue that evolves to liquefaction, facilitating necrosectomy and reducing mortality. The benefits of this strategy are obvious when comparing the mortality of the patients from the 7-28 day group with the mortality in the group of patients with surgery after 28 days of evolution $(26.4 \%$ vs $5.7 \%$ ) (Table 2 ).

It is obvious that the mortality among patients with MODS operated after 28 days is small despite the fact that the organ dysfunction

Table 2. Mortality depending on the presence of MODS and timing of surgery

\begin{tabular}{|c|c|c|c|}
\hline \multirow{2}{*}{$\begin{array}{l}\text { Mortality } \\
(n=27 / 157 \text { cases operated; } 17,1 \%)\end{array}$} & \multicolumn{2}{|c|}{ Timing of surgery } & \multirow[t]{2}{*}{$P$ value } \\
\hline & $\begin{array}{c}\text { Day 7-28 } \\
(n=87)\end{array}$ & $\begin{array}{l}\text { More than } 28 \text { days } \\
(n=70)\end{array}$ & \\
\hline Patients without MODS $(n=1 / 11 ; 9 \%)$ & $1 / 7(14,2 \%)$ & $0 / 4(0 \%)$ & 0.045 \\
\hline $\begin{array}{l}\text { Patients with } 1 \text { transient / persistent } \\
\text { organ dysfunction }(n=9 / 88 ; 10,2 \%)\end{array}$ & $8 / 52(15,3 \%)$ & $1 / 36(2,7 \%)$ & $<0.001$ \\
\hline $\begin{array}{l}\text { Patients with }>2 \text { organ dysfunctions } \\
(n=17 / 57 ; 29,8 \%)\end{array}$ & $14 / 28(50 \%)$ & $3 / 29(10,3 \%)$ & $<0.001$ \\
\hline Total $(n=27 / 157)$ & $23 / 87(26,4 \%)$ & $4 / 70(5,7 \%)$ & \\
\hline
\end{tabular}


occurred at a more advanced stage of the disease. We have applied the principle in selected cases depending on the severity, the occurrence of the complications requiring emergency treatment, the inefficiency of the conservative therapy.

\section{Discussions}

Once the diagnosis has been established, the therapeutic management strategy necessarily requires a series of steps: early recognition of severity (7); fluid resuscitation, supportive therapy and appropriate monitoring $(9,10)$; pain therapy (analgesia) (11); removal of aetiological factors, for example, choledocholithiasis; prevention and early recognition of local and systemic complications; nutrition; specific therapy; indication of surgical treatment, when required. In both stages (early and late) the initial therapeutic protocol requires resuscitation and multidisciplinary approach (5). Due to these measures, the rate of early death by circulatory, respiratory or renal complications can be reduced (11).

Initial treatment of severe forms of acute pancreatitis (12) is conservative, based on fluid resuscitation, analgesia and early enteral nutrition $(13,14)$. Thromboprophylaxis with low molecular weight heparins should be instituted in all patients (15). Patients with acute pancreatitis have a bowel barrier permeability dysfunction involved in the pathogenesis of local and systemic septic complications (bacterial translocation) (10). The infection prophylaxis of local complications by intravenous systemic prophylactic antibiotic therapy is not recommended because of the lack of evidence to justify it and the risks arising from this practice: increased bacterial resistance (by selecting more resistant and aggressive strains) and the occurrence of fungal infections $(16,17)$. Widespectrum early antibiotic treatment in case of high suspicion of infected necrosis or targeted antibiotic therapy when necrosis infection is certified by CT scan guided fine needle aspiration (CT-FNA with antibiogram) has a much more beneficial role than antibiotic prophylaxis (18). The role of prophylactic antibiotic therapy in the prevention of local or systemic septic complications in acute severe pancreatitis is confirmed in the case of invasive procedures such as ERCP with/without papillotomy or other surgical techniques $(19,20)$. Existing comorbidities must be treated intensively $(5,11)$.

The decision of surgery in patients expected to develop severe acute biliary pancreatitis is still under discussion. It is argued that ERCP performed early with / without papillotomy has no beneficial effect in patients expected to develop middle or severe biliary pancreatitis, in the absence of cholangitis. Regarding the operative moment, the laparoscopic cholecystectomy can be performed when the amylase levels return to normal values and the symptomatology is remitted to prevent recurrence (20).

We prefer to apply this approach to moderate and moderately severe forms of acute biliary pancreatitis, while in patients with severe form the attitude has differentiated according to the need for necrosectomy (5). In those who do not require necrosectomy, cholecystectomy appears to be indicated after total recovery, whereas in patients requiring necrosectomy, cholecystectomy was performed concurrently with it, preferably after 28 days of conservative evolution and treatment (5.21).

The central event characterizing the late phase of severe acute pancreatitis is the infection of the necrosis of pancreatic and / or peripancreatic tissue (22). Their infection tends to occur in $10-70 \%$ of cases with pancreatic necrosis and increases mortality (23). The distinction between sterile or infected collections is very important because they have different prognosis and treatment (24).

The unanimous opinion is that surgical intervention is mandatory in certain pancreatic infection, otherwise the progression is fatal $(4,5)$. The diagnosis of certainty of infected necrosis is represented only by the positive bacterial or fungal cultures of CT-FNA-guided aspiration in the suspected necrosis area. False positive results (external contamination of the area under examination) leading to surgical interventions in sterile necrosis are very rare. False negative results can occur in the event of maneuver failure (tapping the wall of a closed necrosis or near a collection) and are around 15\%. 
Therefore, a case selection is required. Patients with severe acute pancreatitis with oscillating clinical progression that do not stabilize in the first 3-4 weeks of evolution without an identifiable source of infection, without gas bubbles at the necrosis site on high-contrast CT scan or clinical high suspicion of pancreatic necrosis infection are ideal candidates for performing CT-FNA (25). When gas bubbles are evident in radiological scans, CT-FNA is no longer necessary. In our study for situations where CT-FNA was not possible, we defined the term of high suspicion of pancreatic infection (ISIP) using the following criteria: worsening of the general condition after a favorable evolutionary period, persistence, recurrence, or a new febrile episode $>38^{\circ} \mathrm{C}$ ) for more than 48 hours, leukocytosis $>16,000 / \mathrm{mm}^{3}$ and persistent MODS (5).

The reason for surgical debridement in severely infected severe pancreatitis is based on two major aspects. The first is the careful but aggressive removal of the necrotic intra and extrapancreatic tissue as well as the ascites fluid from the omental burdens and the peritoneal cavity. The second aspect is the preservation of viable pancreatic tissue (26). Multiple organ dysfunctions (MODS) may be an operative indication if it persists greatly or significantly damages the patient's general status at any given time, despite the intensive intensive care treatment for at least 4 weeks. (27) With regard to choosing the optimal moment of surgery, we prefer late interventions, if possible (ideally after 28 days of onset of acute pancreatitis) due to a better demarcation of necrotic tissue (5).

Necrosectomy and drainage of infected collections / necrosis may be performed using other procedures than open surgery (5,28-30). These alternative surgical techniques continue to evolve, being known collectively as "minimalinvasive necrosectomy / debridement." They are classified according to the visualization method (radiographic, endoscopic, laparoscopic, hybrid / simultaneous mixed / stepped), the pathway followed (oral, transpapillary or transmural, percutaneous retroperitoneal, trans peritoneal percutaneous, transmural percutaneous etc., according to taxonomy developed by Windsor and his colleagues. These minimally-invasive techniques are designed to reduce operator stress for as much as that of open, classical surgical debriding. The applicable surgical techniques are: open necrosectomy, percutaneous drainage, endoscopic approach, laparoscopic approach, retroperitoneal video-assisted approach. The current trend is to combine these techniques, hybrid techniques, based on the idea of progressive approach from minimally invasive to classic (step-up philosophy) $(6,12)$. Combining these techniques within the same patient can have far more beneficial effects than the monomodal approach (5).

\section{Conclusions}

The key to therapeutic success is the early treatment, in the first 12-24 hours of onset because it has been found that the highest incidence of organ dysfunction is within this range. Early treatment of severe acute pancreatitis is focused on conservative therapy to prevent the development of organ dysfunction. This rule makes exception to the bile etiology that requires endoscopic or surgical intervention.

Surgery is considered the "gold standard" in the treatment of certified infected pancreatic necroses. We believe that the success of the minimally invasive approach also depends greatly on selecting the cases to be subjected to such interventions. The chances of success increase with the passing of time from the debut (>28 days) on closed infected necroses. The laparoscopic approach should be performed by a team with extensive experience in both minimally invasive and classical open surgery. Different reported successes in one technique are difficult to accurately compare because the "hidden" effects of patient selection, co- $^{-}$ morbidities of the case, preoperative management (radiological interventional or endoscopic) as well as surgical indication are impossible to quantify.

On the other hand, we emphasize that there is no universal approach applicable to all patients with severe acute infected pancreatitis, so that the ideal surgical management for a 
particular patient should be determined on the basis of individual clinical development.

\section{Conflict of Interest: none declared.}

\section{References}

1. Banks PA, Bollen ThL, Dervenis C, Gooszen HG, Johnson CD, Sarr $M G$, et al. Classification of acute pancreatitis - 2012: revision of the Atlanta classification and definitions by international consensus. Gut Published Online First: 25 October 2012. Available from: http://gut.bmj.com/content/early/2012/10/24/gutjnl-2012-302779. full.pdf+html

2. Sarr MG. Revision of the Atlanta classification of acute pancreatitis 2012. Article ID: AOP_13_010, Polish Archives of Interna Medicine, 2013. Available from: http://www.pamw.pl/sites/default/ files/PAMW 2013-3 Sarr 0.pdf

3. Windsor JA, Petrov MS. Acute pancreatitis reclassified. Gut Published Online First: Nov 8, 2012. Available from: http://gut.bmj. com/content/early/2012/11/07/gutjnl-2012-303725.

4. Dellinger EP, Forsmark CE, Layer P, Lévy P, Maraví-Poma E, Petrov MS, et al. Determinant-based classification of acute pancreatitis severity: an international multidisciplinary consultation. Ann Surg. 2012;256(6):875-80.

5. Cochior D, Constantinoiu S. Severe acute pancreatitis - clinical and paraclinical approach based on determinants factors. Bucuresti: Editura Carol Davila; 2015

6. Petrov MS, Vege SS, Windsor JA. Windsor. Global survey of controversies in classifying the severity of acute pancreatitis. Eur $J$ Gastroenterol Hepatol. 2012;24(6):715-21.

7. Petrov MS, Windsor JA. Conceptual framework for classifying the severity of acute pancreatitis. Clin Res Hepatol Gastroenterol. 2012;36(4):341-4

8. Popa F, Bratucu M, Radu P, Iorga C, Garofil D, Cuibac A, et al Septic remnants, a crucial factor in the outcome of suppurated pancreatitis. Chirurgia (Bucur) 2013; 108: 7-12. Romanian

9. Pezzilli R. Fluid Replacement Strategy in Severe Acute Pancreatitis. Pancreatic Dis Ther. 2013;S2:001.

10. Foitzik T, Hotz HG, Kinzig M, Sörgel F, Buhr HJ. Influence of changes in pancreatic tissue morphology and capillary blood flow on antibiotic tissue concentrations in the pancreas during progression of acute pancreatitis. Gut. 1997;40(4):526-30.

11. IAP/APA evidence-based guidelines for the management of acute Pancreatitis. Pancreatology 13, e1-e15, 2013Published by Elsevier India, a division of Reed Elsevier India Pvt. Ltd. http://dx.doi.org/ 10.1016/j.pan.2013.07.063

12. Petrov MS, Windsor JA. Classification of the severity of acute pancreatitis: how many categories make sense? Am J Gastroenterol. 2010;105(1):74-6. doi: 10.1038/ajg.2009.597. Epub 2009 Oct 20.

13. Perera MRS, Tattersall MZ, Wysocki AP. Analgesia in Patients with Acute Pancreatitis - A Cry for Help. International Journal of
Gastroenterology Research and Practice. Volume 2014 (2014). Article ID 343907

14. Bajwa SJ, Gupta S. Controversies, principles and essentials of enteral and parenteral nutrition in critically ill-patients. J Med Nutr Nutraceut 2013;2:77-83.

15. Guidelines for intensive care unit admission, discharge, and triage. Task Force of the American College of Critical Care Medicine, Society of Critical Care Medicine. Crit Care Med. 1999;27(3):633-8.

16. Petrov MS, Shanbhag S, Chakraborty M, Phillips AR, Windsor JA. Organ failure and infection of pancreatic necrosis as determinants of mortality in patients with acute pancreatitis. Gastroenterology. 2010;139(3):813-20.

17. Popescu I. Management of acute severe pancreatitis. Chirurgia (Bucur). 2006;101(3):225-8. Romanian

18. Thoeni RF. The revised Atlanta classification of acute pancreatitis: its importance for the radiologist and its effect on treatment. Radiology. 2012;262(3):751-64. doi: 10.1148/radiol.11110947.

19. Choudhary A, Bechtold ML, Arif M, Szary NM, Puli SR, Othman $M 0$, et al. Pancreatic stents for prophylaxis against post-ERCP pancreatitis: a meta-analysis and systematic review. Gastrointest Endosc. 2011;73(2):275-82.

20. Freeman ML, Nelson DB, Sherman S, Haber GB, Herman ME, Dorsher $\mathrm{PJ}$, et al. Complications of endoscopic biliary sphincterotomy. N Engl J Med. 1996;335(13):909-18.

21. Cheung MT, Li WH, Kwok PC, Hong JK. Surgical management of pancreatic necrosis: towards lesser and later. J Hepatobiliary Pancreat Sci. 2010;17(3):338-44.

22. Bratucu E, Marincas M, Daha C, Simion L, Stanescu AC, Constantinescu T. Retropancreatic approach in the treatment of pancreatic suppurations. Chirurgia (Bucur). 2009;104(5):645-50. Romanian

23. Besselink MG, van Santvoort HC, Boermeester MA, Nieuwenhuijs $\mathrm{VB}$, van Goor $\mathrm{H}$, Dejong $\mathrm{CH}$, et al. Timing and impact of infections in acute pancreatitis. Br J Surg. 2009;96(3):267-73.

24. Wu BU, Johannes RS, Kurtz S, Banks PA. The impact of hospitalacquired infection on outcome in acute pancreatitis. Gastroenterology. 2008;135(3):816-20.

25. Wu BU, Banks PA. Clinical management of patients with acute pancreatitis. Gastroenterology. 2013;144(6):1272-81.

26. Loveday BP, Petrov MS, Connor S, Rossaak JI, Mittal A, Phillips AR, et al. A comprehensive classification of invasive procedures for treating the local complications of acute pancreatitis based on visualization, route, and purpose. Pancreatology. 2011:11(4):406-13.

27. Johnson CD, Abu-Hilal M. Persistent organ failure during the first week as a marker of fatal outcome in acute pancreatitis. Gut. 2004;53(9):1340-4

28. Pezzilli R, Uomo G, Zerbi A, Gabbrielli A, Frulloni L, De Rai P, et al. Diagnosis and treatment of acute pancreatitis: the position statement of the Italian Association for the study of the pancreas. Dig Liver Dis. 2008;40(10):803-8

29. Bucher P, Pugin F, Morel P. Minimally invasive necrosectomy for infected necrotizing pancreatitis. Pancreas 2008; 36(2):113-119.

30. Branum G, Galloway J, Hirchowitz W, Fendley M, Hunter J. Pancreatic necrosis: results of necrosectomy, packing, and ultimate closure over drains. Ann Surg. 1998; 227(6):870-877. 